\title{
Extension Communication Fisherwomen in Ecotourism Management in Small Islands
}

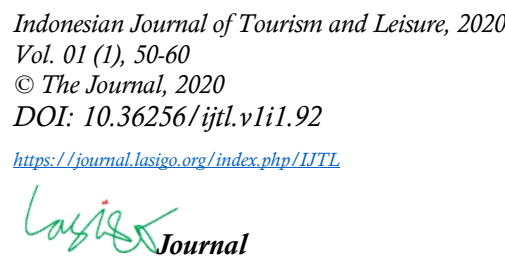

Accepted : April 15 2020

\section{Khodijah Ismail}

Department of Fisheries Social Economic, Marine and Fisheries Faculty, Universitas Maritim Raja Ali Haji, Tanjungpinang, Riau Islands

khodijah@umrah.ac.id

\section{Sayyidah Nur Habibah}

Department of Integrated Natural Resources Management, Graduate Program, Universitas Andalas, Padang, West Sumatra

sayyidahhabibah@gmail.com

\begin{abstract}
The purpose of this study was to determine the effectiveness of extension communication among fisherwomen in the management of eco-tourism. This research was conducted in the tourist area of Benan Island, Lingga Regency, Riau Islands Province, using a mixed method, which is a combination of qualitative and quantitative research methods. The results of the analysis conclude that fisherwomen are said to be effective in conducting extension education to support sustainable eco-tourism management in the village. This is seen from the effectiveness value of several components in the effective category range (330-540), among others the frequency of Extension conducted by fisherwomen to the family environment and surrounding communities has a value of 380 , the value of the level of knowledge about the goals of eco-tourism management obtained by the community from extension communication is 370 , and the value of implementing sustainable eco-tourism management by the surrounding community of 360 . Extension communication methods with individual direct dialogue are considered more effective (380) compared to direct group dialogue (253). This indicates that fisherwomen need a higher intensity of training in order to increase their knowledge and skills as well as their involvement in ecotourism management in the village.
\end{abstract}

Keywords: Extension Communication, Ecotourism, Fisherwomen, Effectiveness

\section{Introduction}

Indonesia has great potential for the development of ecotourism with a wealth of natural and cultural environmental resources spread over 17,475 small islands that are expected to reduce the problem of poverty in coastal areas. Specifically Riau Islands, with its strategic location adjacent to neighboring countries (Malaysia and Singapore) and has thousands of islands (2,408 islands)

Corresponding Author 
and 95 percent of the sea area, also grows and develops its ecotourism to small islands. The socioeconomic conditions of the small and foremost island communities that are tourist destinations have not shown significant progress as a result of the development of tourism in the region (Khodijah, 2014). Moreover, it is known that the household welfare ranking of small island coastal communities is still relatively low (Khodijah, 2013). A report from UNWTO (2019) found that to advance tourism's contribution to the SDGs and achieve our common goals on gender equality, mainstreaming gender considerations in the tourism sector is very important.

Benan Island is one of the very attractive tourist destinations in the Regency of the Riau Islands. Today Benan Island has also become the district capital, which was previously only a fishing village. The development of ecotourism on Benan Island has an impact on the livelihoods of fishermen and fishermen's wife. Benan Island has a tour management group that is in charge of preparing needs and serving the visitors. The rapid development of tourism here has not been accompanied by advances in the capacity of the mothers of Benan Island. So that in the management of tourism in the village of Benan Island fisherwomen have not been able to actively participate. On the other hand the existence of Benan Island's ecotourism is actually an opportunity for fisherwomen to get additional income. Tourism development has many environmental, economic and socio-cultural benefits. Small islands have a lot of potential for the development of marine tourism (Ismail, 2015). Benan Island is known to have beautiful beaches and potentially beautiful coral reefs and Benan Island tourism objects are increasingly being looked at by world tourists (Linggakab.go.id, 2015).

The global report on women in tourism in 2019 highlighted how tourism as a vehicle for empowerment and development. It is known that more and more women are challenging gender stereotypes in this sector and taking roles that were once dominated by men such as tour guides. Technology is an important factor for empowerment, giving women more training opportunities and stimulating women's entrepreneurship through easier access to the tourism market. Policy makers are more aware of the importance of gender equality in tourism and implement measures to ensure women share the benefits that tourism can bring.

The UNWTO report states that the majority of tourism workers throughout the world are women, 54 percent of people working in tourism are women compared to 39 percent in the wider economy. Wage gap is smaller in the tourism industry - women in tourism earn 14.7 percent less than men. And tourism offers women greater opportunities for leadership roles - 23 percent of tourism ministers are women compared to 20.7 percent of ministers as a whole (UNWTO, 2019) UNWTO (2019). In addition, women play an important role in the conservation and sustainable management of ecosystems. Since ancient times, women have traditionally been involved in protecting and preserving local natural resources (Singh, 2014). Even when feminist political ecologists clearly show the importance of gender relations with the struggle for sustainable natural resources, feminists work on a range of topics where gender is not the main analytical variable (Sundberg, 2017). However, many studies say that the level of women's involvement in the management of ecotourism is relatively low (Cadika indrawati, Darwis, 2017; Rahayu, 2018; Andani, 2017; Subekti, 2017). Therefore, the role of extension communication is expected to increase women's participation in ecotourism management.

\section{Theoretical Framework}

\subsection{Ecotourism Management}

One characteristic of the debate about community-based ecotourism and tourism (CBT) is that there has been little effort to document the development impact of the approach; the idea is tempting, but there is little evidence of the net benefits to local communities or conservation. On the other hand the economic potential of tourism is so important in poverty alleviation especially areas that depend on sun, sand and sea tourism (Goodwin, 2008). Ecotourism is activities that 
combine conservation activities and benefits for local communities where it relies heavily on tourism activities on nature and environmental sustainability (Firdaus \& Tutri, 2017).

In the ecotourism paradigm (figure 1), Orams argues that the majority of the definition of ecotourism lies between the passive position and the active position towards the pole of high responsibility on the continuum. He further suggested that the desired state was to move from the minimum passive position towards the higher or active poles of the continuum. The main pole actively emphasizes actions to protect the environment and behavioral intentions of ecotourism, while the passive position only concentrates on the development of ecotourism, does not increase the impact of antagonists or ecotourism needs to be met (Diamantis \& Roches, 2017).

Figure 1. The continuum of ecotourism paradigms Orams (1995)

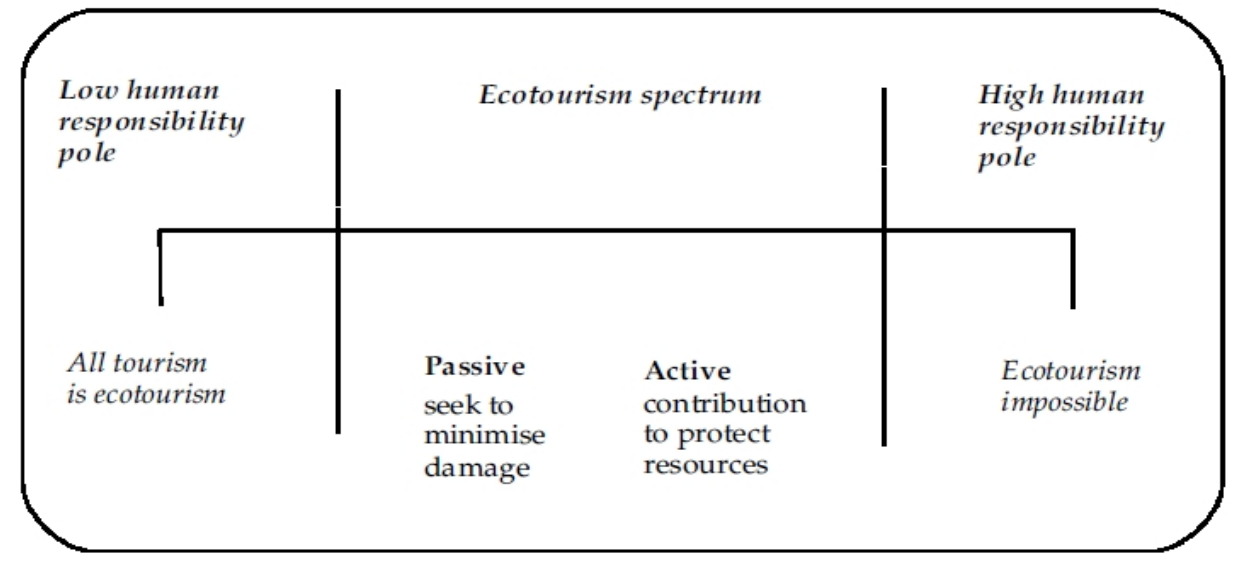

Source: Diamantis \& Roches, (2017)

Tourism is often seen as an industry that benefits the elite. How do we increase awareness within government, and among national decision makers in other sectors, about the contribution of tourism to local livelihoods and involve them in joint initiatives to enhance local economic development and the impact of poverty reduction? If growth in favor of the poor and poverty reduction through tourism is to be part of a national strategy, then it is important to involve other national government ministries. This requires that positive impacts on local and national economies and specifically success in achieving poverty reduction targets can be demonstrated, measured and reported conclusively (Anderson, 1988).

\subsection{Women's Empowerment in Ecotourism Management}

Development is not a neutral and friendly process, but a process that occurs in the context of global restructuring, where gender inequality is a fundamental component. Although many aspects of tourism development policy do not contain a clear gender component, implicit gender assumptions remain. In tourism development policies the idea of women's empowerment is very limited, economic empowerment is used to justify and legitimize policies. That is, empowerment through the market remains empowerment in the market, leaving aside broader social change. Although tourism development can reshape gender power relations in narrow economic (or market) terms, in reality the broader power structure of inequality in all societies remains gender biased, a pattern which in many cases is not only strengthened but also driven by the development process tourism (Ferguson, 2009).

The power of tourism is that it can help improve livelihoods by reducing poverty, ensuring or increasing environmental sustainability, and promoting gender equality and empowering women. There are no regions in developing countries where women appear to be equal to men in terms of legal, social and economic rights. This gender gap affects the access and control of resources, 
political voice, in economic opportunities and power relations. In the end, the costs of this inequality cut widely throughout society and ultimately hurt everyone (Ateljevic, 2008).

\subsection{The Role of Extension Communication in Tourism Development}

The extension method/process in capacity building is considered the most important communicative interaction needs, but still faces inadequate conditions (Okojie, 2013). Development communicators have an important contribution to increase joint action and shared knowledge creation through interactive learning to the status of governance mechanisms that are equal to technology, hierarchy, and markets (Röling, 2004). Lack of human resource capacity, especially at the field level, can frustrate government efforts. Extension agents need communication training for development, which is useful for overcoming problems, such as participation, integration and capacity building for them to deal more effectively with development partners (Agunga \& Manda, 2014).

Extension aims to change the views and attitudes of the agricultural community in general and strive to improve tourism operations and the lives of families in totality on their own initiative. Because most tourism actors are small and marginal, they do not have direct access to develop tourism technology. Educating such groups of tourism operator must, therefore, be an ongoing process to compensate for rapidly changing tourism technologies. The aim of the extension program depends on the socio-economic conditions of the people in the area and needs to transmit the latest developments in tourism industry to meet their needs. Thus, the objectives have been set in all these programs especially:

1) to help people identify their problems and feel and meet needs;

2) to develop leadership among various sectors of rural society;

3) to send information based on tourism research and applied experience with a view to bringing a larger tourism community under modern technology;

4) to continue to inform research workers about problems at the tourism level to offer solutions based on further research in the specific field concerned.

Extension philosophy is mainly based on (1) the development of individual and (2) interactions in various sectors of rural communities that must be avoided in unbalanced development, extension services are presented with the aim of planning, implementing and evaluating technology adopted by farmers. Extension aims to teach the community and motivate them to bring the latest developments into practice through spontaneous responses (Murray, 2014).

\subsection{Effective Communication}

The effectiveness of communication can determine success in extension activities. Communication can be said to be effective if it can convey what it means. Tubbs and Moss (1996) as quoted by Ropiah (2010) state that effective communication is communication in which the simulated meanings are similar or the same as those intended by the communicator. If $\mathrm{S}$ is the sender and $\mathrm{R}$ is the recipient of the message, then communication is said to be effective if the desired response $\mathrm{S}$ and $\mathrm{R}$ are the same.

Affective effects cause changes in attitude in the recipient due to the message received. communication will be effective if the communicator adjusts his communication with the communicant, namely understanding the communicator's interests, needs, experiences, difficulties and abilities. Tubbs and Moss (1974) suggest that effective communication has five signs, namely:

a) Definition is a careful acceptance of the contents of the message delivered by the communicator so that there is no misinterpretation of the message by the communicant. 
b) Fun is an atmosphere that makes the relationship to be warm, intimate and pleasant. The level of pleasure in communicating is closely related to feelings towards people who interact.

c) Influencing attitudes, namely the persuasive ability of communicators in conveying messages that have an effect on the communicant self.

d) A good social relationship that is the feeling of wanting to join with others, wanting to control and be controlled

e) Actions are real actions taken by the communicant after understanding, forming and changing attitudes and the growth of good relationships (Rakhmat, 2001).

A fundamental requirement in measuring effectiveness and in evaluating potential policies is the identification of a series of inputs given that have a homogeneous relationship with participant outcomes (Lockheed \& Hanushek, 1994). From an economic perspective, what is effective is not necessarily effective at the community level. Effectiveness in the utilization of resources is the widest of the concepts of effectiveness, because it is related to the process of utilization in the broadest sense in various dimensions (Poskart, 2014). The communication effectiveness approach can use a qualitative approach.

Ecotourism management activities are closely related to participation because participation is a form of community involvement in order to receive benefits from the development of ecotourism in his village. Extension activities are one way in realizing sustainable ecotourism management in Indonesia, and the role of extension workers is very important to increase community participation in coastal villages. The explanation above can be formulated in the form of a research framework in Figure 2.

Figure 2. Research Framework

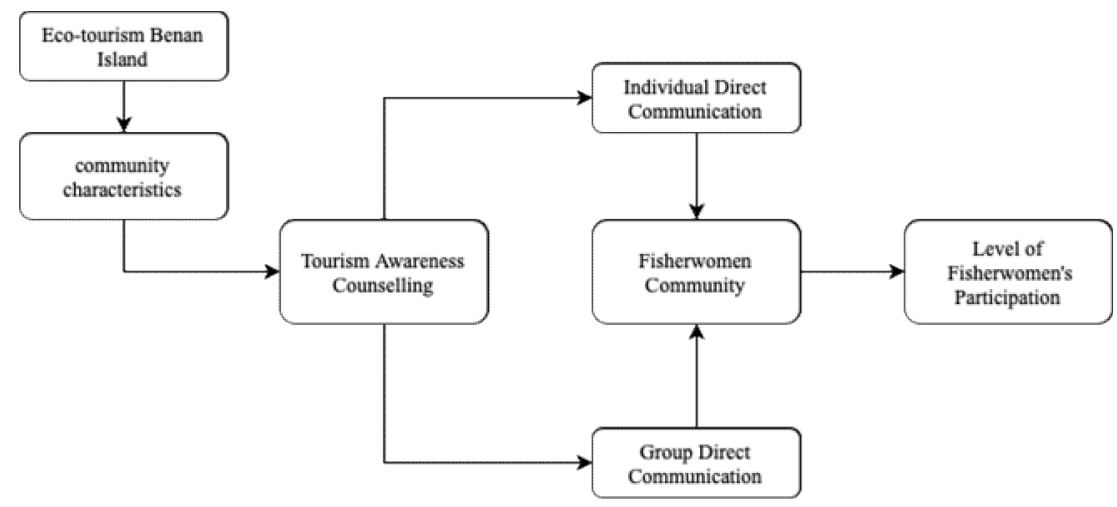

\section{Method}

The research method used in this study is a mixed method that is a combination of qualitative and quantitative research methods (Almalki, Centre, Arabia, \& Centre, 2016); (Terrell \& Ph, 2012). Research data collection was carried out by field research, using several techniques namely observation techniques, interview techniques, questionnaire techniques. The data analysis technique is carried out several stages starting from editing / verification, tabulating, analiting, and concluding. Based on the data collected qualitative data is converted into quantitative data, then descriptive analysis is used. Descriptive data analysis, which explains the effectiveness of communication between fisherwomen extension in ecotourism management. The basic data is compiled by using a frequency distribution table and measuring using a Likert scale.

This analysis is used to find out the percentage of respondents' questionnaire answers. The formula used is: 


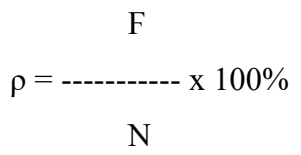

Information:

$\mathrm{P}=$ Answer Presentation

$\mathrm{F}=$ Frequency (Number of answer)

$\mathrm{N}=$ Number of Question

For the questionnaire answers, the writer uses the following categories:

nalisis ini digunakan untuk mengetahui besarnya persentase jawaban angket dari responden. Rumus yang digunakan adalah :

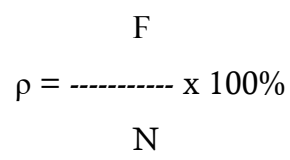

$\mathrm{P}=$ Persentase jawaban

$\mathrm{F}=$ Frekuensi (jumlah jawaban)

$\mathrm{N}=$ Jumlah pertanyaan

Untuk jawaban angket, penulis menggunakan kategori sebagai berikut:

Table 1. Score Scale

\begin{tabular}{lll}
\hline Category & Score & Information \\
\hline Frequent & 3 & Efective \\
\hline Rare & 2 & Less Effective \\
\hline Never & 1 & Not Effective \\
\hline
\end{tabular}

Furthermore, to assess the effectiveness of the extension method the class interval and class range values are used, i.e :

Highest score = Highest score $\mathrm{x}$ Number of samples $\mathrm{x}$ Number of questions

Lowest Value = Lowest score $\mathrm{x}$ Number of samples $\mathrm{x}$ Number of questions

Class interval = (highest number - lowest number) $/$ class number

After that it is formulated using the effectiveness category.

Research respondents are people who can provide answers or information about the research variables to be conducted. In this study, the study respondents referred to were fisherwomen domiciled in Benan Island, totaling 28 people who were determined by purposive sampling method (Moleong, 2001), namely fisherwomen who were involved in ecotourism management activities in the village. To obtain qualitative data, in-depth interviews were conducted with several key informants (Yin, 1989) who understand well the history and development of ecotourism management in Benan Island.

\section{Results}

\subsection{Research Location Profile}

Lingga Regency was formed based on Law No.31 of 2003 which is located between $0^{\circ} 20^{\prime}$ North Latitude with $0^{\circ} 40^{\prime}$ South Latitude and $104^{\circ}$ East Longitude and $105^{\circ}$ East Longitude, 
with an area 45.456,7162 km2 (land area 2.117,72 km2 and Seas 43.338,9962 km2). Lingga Regency consists of 531 islands and 5 districts, one of which is Senayang District. Senayang Subdistrict is located in the north of the capital city of Lingga Regency and is located between $0^{\circ}$ 02'25" North Latitude and 104'39'07" East Latitude, with regional boundaries namely North of Batam City and Tanjungpinang City, East of Natuna Sea, South of North Lingga District and to the west of the Ketaman Strait, Inderagiri Hilir Regency. Senayang Subdistrict consists of 369 islands which are spread both large and small islands. One of the small islands contained in the Senayang District is Benan Island. Benan Island has a very strategic location that is located in the front of the group of islands from the direction of Batam and Bintan which is the main access to the Riau Islands Province. This island is located at position $0^{\circ} 21^{\prime} 30^{\prime \prime}$ - 0 $244^{\prime} 44^{\prime \prime}$ LU dan $103^{\circ} 20^{\prime} 40^{\prime \prime}-103^{\circ} 31^{\prime} 53^{\prime \prime}$ "with an area of $500 \mathrm{~km} 2$. Based on the size and size of the island, Benan Island is said to be a small island, in accordance with Law No. 27 of 2007 concerning Management of Coastal Areas and Small Islands. Today Benan Island is known as one of the islands which is a marine tourism village because of its underwater beauty (DKP Provinsi Kepri, 2011).

Benan Island is the remnant of erosion or shrinkage from the pre tertiary land that stretches from Peninsular Malaysia / Singapore Island in the north to Kundur Island and Karimun in the South. Land surface classified as flat with variations in the hills and rocky young. Benan island area and its surroundings is a group of small islands that have coastal land vegetation is still in good condition, the types of plants that are mostly found are coconut trees, nibung, mango, pandanus, sweet potatoes and mangroves. The white sandy beach, and the waters of this region also have coral reefs and seagrass fields that are very beautiful, with a variety of fish species. Seen from Benan Island included in the tropical climate region, which generally consists of 6 rainy seasons (October-April) and 6 dry seasons (April-October). The air condition is quite fresh and clean because the pollution factor is relatively low. The average annual rainfall is between 7,6 $\mathrm{mm}-1 / 000 \mathrm{~mm}$. Low average temperatures are $23^{\circ} \mathrm{C}$ and highest are $30^{\circ} \mathrm{C}$, Humidity between $62-98 \%$. The distance to the capital of the sub-district is $50 \mathrm{~km}$, which takes 5 hours (sea route), then the distance to the capital of the district is $150 \mathrm{~km}$ with a time of 7 hours and the distance to the provincial capital is $250 \mathrm{~km}$ with a time of 4 hours (BAPPEDA Lingga, 2011).

The high access and control of women to the management of coastal resources is expected to increase economic capacity. In order to achieve the goal of sustainable ecotourism management in the coastal islands of small islands, active participation of coastal women is needed. To encourage the active role of coastal women is a big challenge considering that generally only men have a primary role in village decision making. One way to encourage potential village women to become community mobilizers is to make coastal women as extension agents in the village. In extension activities women can train their ability to communicate, express opinions, the planning process and decision making in the management of ecotourism in the village.

\subsection{Analysis of the Effectiveness of Fisherwomen's Communication}

The extension method was carried out in Benan Island's village in two stages, namely a group of fisherwomen getting extension from extension workers assigned by the government and then this group of fisherwomen continued the extension activities to the local community. This was done because of the limited number of existing government extension agents, the existence of targeted extension agents spread across small islands with a distant location, the low interest of government extension agents domiciled in small island areas, the limited extension time owned by extension workers. So that the existence of a fishing women's group as an extension agent in the village is very helpful to the government program.

To find out the effectiveness of extension carried out by a group of fisherwomen, there were 3 questions assessed with assessment indicators:

- The frequency of getting extension 
- Knowledge of the goals of ecotourism management

- Implementation of ecotourism management by the community.

\subsubsection{The Frequency of Getting Counselling}

From the analysis results it is known that the frequency of getting extension from fisherwomen's groups is in the range of 330-540 (380), which means that the extension activities carried out by fisherwomen's groups are said to be effective, this is due to the intensity of the meeting of fisherwomen's groups both with their respective husbands and with the local community the frequency is higher compared to the time of extension conducted by government extension workers. In addition, a group of fisherwomen who are familiar in the midst of the village community find it easier to adapt to the community to convey the purpose of extension.

\subsubsection{Knowledge of the Goals of Ecotourism Management}

This is also evidenced by the level of public knowledge of the purpose of extension carried out. The community who know well the objectives of the extension activities carried out by fisherwomen groups reached $78 \%$ with an effectiveness level in the range 330-540 (370) which means effective. The villagers are known that they are very familiar with the purpose of extension activities to provide a good understanding of the sustainable ecotourism management efforts in the village.

\subsubsection{Implementation of Ecotourism Management by the Community}

Likewise with other assessment indicators, where the level of effectiveness of the community regarding the goals of ecotourism management in the village's coastal areas is said to be effective with a range of 330-540, namely 360. Although formal education levels are good, the group of extension workers from fishery women or the target group consisting of several groups the community is classified as very low but they get a lot of good knowledge from various socialization activities carried out in this village. In addition to village outreach activities it is also often used as a research location for students. Due to the time when the socialization activities were carried out the fishermen carried out their routine to go to sea (catching fish), the community group that gained a lot of knowledge from the socialization activities carried out was a fisherwomen's group. Then due to the group of fisherwomen who have gained this knowledge more time to gather with other community groups including other coastal women so the extension activities are very relevant said to be effectively carried out by the fisherwomen's group.

The final results of the success of extension activities carried out by fisherwomen can be seen from the implementation of ecotourism management around the coast of small islands by the local community. Massive support from the community for sustainable ecotourism management can be seen from the positive activities that support that goal. People who used to cut down ecotourism for various purposes now they have understood it well by not doing activities that can damage the ecotourism ecosystem. The level of effectiveness for indicators of the implementation of ecotourism management by the community is said to be effective because it is in the range of 390 - 540 namely 370. Good effectiveness for all assessment indicators is also supported by nonformal institutions built by women such as PKK organizations and social gathering of RT / RW mothers in this village. It is through these social activities that female extension workers carry out their extension roles well and are accepted by many. Although formal education is relatively low, coastal women in this village have actively participated in existing non-formal organizations. Through this organization they also gained a lot of informal knowledge.

\section{Discussion}

The existence of small islands that have very attractive tourism potential but are difficult to access because they are separated by a considerable distance from the city center and limited 
transportation, require high involvement from all components of the local community. From the context of extension, it still faces constraints of limited human resources both in terms of the quantity and quality of counselors. So that the role of women who have more time compared to men in villages that are mostly at sea is expected to be able to continue the extension mission to realize sustainable ecotourism management in tourist villages.

In the concept of sustainable ecotourism management, community involvement, including women, is important to realize long-term goals. However, several previous studies explain the low involvement of women in development, including the development of ecotourism. Some research confirms the importance of the role and involvement of women in development (Andani \& Musadad, 2017); (Ateljevic, 2008); (Putri et al., 2017); Applying a gender lens involves looking at how gender social relations and fundamental power dynamics affect men's and women's participation and benefit from development (Terefe, 2020). The role of women needs to be certified in various programs that increase their capacity to deal with issues related to rural development and village ecosystem management (Singh, 2014). However, this research approach does not use a gender analysis approach, it still measures how effective women are in extension.

In accordance with the function of extension that is to change knowledge, attitudes and skills (Murray, 2014), then this research shows that extension can be done informally using a personal approach. Understanding public knowledge about the importance of ecotourism sustainability in the region becomes important to be conveyed inter-personally in the community.

In contrast to research conducted in a tourist village that is not based on marine tourism above, know that women psychologically have a sense of pride and empowerment in ecotourism activities in their villages so that women interact with visiting tourists. Of the three dimensions measured (psychological, social and political dimensions), the lowest value is the political dimension. That at the village level the involvement of women in the decision making process for the advancement of tourism is very small. This research uses Resident Empowerment through Tourism Scale (RETS) analysis (Rahayu, 2018). In other studies mentioned women have a role to promote tourism in his village (Subekti, 2017).

The limited number of extension agents in the management of ecotourism in the small islands area encourages fisherwomen in coastal villages to take on the role of chain educators promoting the importance of sustainable ecotourism management in their villages. Government intervention is expected to improve the knowledge, attitudes and skills of village fishermen extension workers.

\section{Conclusions}

Based on the results of the analysis and referring to the research objectives, the conclusions obtained are that overall the indicators of the assessment of the effectiveness level of fisherwomen as extension agents are all declared effective. So that the active participation of women in extension activities has a positive impact on the management of ecotourism on Benan Island. The active involvement of women as extension agents in the village proves that fisherwomen have excellent potential to support various government programs on small islands, especially extension activities. The approach used is a personal approach. However, their knowledge, attitudes and skills need to get government intervention through empowerment and training programs simultaneously.

\section{Acknowledgment}

Thank you to Department of Marine and Fisheries UMRAH and Fisherwomen Center Organization for supporting the implementation of this research.

\section{Conflicts of Interest}

The author states the contents of this article are free from conflicts of interest 


\section{References}

Agunga, R., \& Manda, L. Z. (2014). Communication for Strengthening Agricultural Extension and Rural Development in Malawi. Journal of Development and Communication Studies, 3(1), $1-16$.

Almalki, S., Centre, E. L., Arabia, S., \& Centre, E. L. (2016). Integrating Quantitative and Qualitative Data in Mixed Methods Research - Challenges and Benefits, 5(3), 288-296. https://doi.org/10.5539/jel.v5n3p288

Andani, F., \& Musadad. (2017). Peran Perempuan Dalam Kegiatan Pariwisata Di Kampung Wisata Tebing Tinggi Okura Kota Pekanbaru. Jurnal Online Mahasiswa (JOM) Bidang Ilmu Sosial Dan Ilmu Politik, 4(2), 1-11.

Anderson, L. (1988). Tourism and Local Economic Development: A Bibliography. Vance Bibliographies.

Ateljevic. (2008). Women empowerment through tourism Women empowerment. The Netherlands.

BAPPEDA Lingga. (2011). Feasibility Study Pulau Benan dan Pulau-Pulau Sekitarnya. Lingga: BAPPEDA Kabupaten Lingga.

Diamantis, D. (1999). The Concept of Ecotourism: Evolution and Trends. Current Issues in Tourism, 2(2-3), 93-122. https://doi.org/10.1080/13683509908667847

Diamantis, D., \& Roches, L. (2017). The Concept of Ecotourism : Evolution and Trends The Concept of Ecotourism: Evolution and Trends. Tourism, Vol. 2, No(March 2010). https://doi.org/10.1080/13683509908667847

Ferguson, L. (2009). Analysing the Gender Dimensions of Tourism as a Development Strategy. Madrid, Spain.

Firdaus, F., \& Tutri, R. (2017). Potensi Pengembangan Ekowisata Di Nagari Kotobaru, Kecamatan X Koto, Kabupaten Tanah Datar, Sumatera Barat. Jurnal Kawistara, 7(2), 115206. https://doi.org/10.22146/kawistara. 13570

Goodwin, H. (2008). Tourism, local economic development, and poverty reduction. Applied Research in Economic Development, 5(3), 55-64.

Ismail, K. (2015). Gender Inequality on Marine Tourism Development in Small Island. IOSR Journal Of Humanities And Social Science Ver. III, 20(7), 53-58. https://doi.org/10.9790/083720735358

Khodijah. (2013). Peringkat Kesejahteraan Rumah Tanga Nelayan yang Dikepalai Perempuan Bintan Kepri. Jurnal Dinamika Maritim, 3(1).

Khodijah. (2014). Sustainable livelihoods of fishermen households headed by women (case study in Riau Islands Province of Indonesia). Asian Social Science, 10(9). https://doi.org/10.5539/ass.v10n9p187

Linggakab.go.id. (2015). Potensi Wisata Maritim Pulau Benan Dikenali Dunia. Retrieved February 16, 2020, from http://www.linggakab.go.id/2015/08/14/potensi-wisata-maritimpulau-benan-dikenali-dunia/

Lockheed, M. E., \& Hanushek, E. A. (1994). Concepts of Educational Efficiency and Effectiveness (No. HROWP 24).

Murray, E. V. (2014). Role of Extension in Rural Development. https://doi.org/10.13140/2.1.1524.1608

Okojie. (2013). Identification of Communcation Needs of Extension Agents in. Journal of Agriculture and Veterinary Science, 4(1), 1-6.

Poskart, R. (2014). A Definition of The Concept of Economic Effectiveness. Central Eastern European Journal of Management and Economics, 2(3), 179-187.

Putri, C. indrawati, Darwis, R. S., \& Taftazani, B. M. (2017). Peran Perempuan dalam Pengembangan Program Desa Wisata. Jurnal Penelitian \& PKM, 4(2), 184-187.

Rahayu, A. T. (2018). Gambaran Keberdayaan Perempuan di Desa Wisata Pentingsari berdasarkan Resident Empowerment through Tourism Scale ( RETS ). Gadjah Mada Journal of Tourism Studies, 1(1), 1-11.

Rakhmat, J. (2001). Psikologi Komunikasi. Jakarta: Remaja Rosdakarya.

Röling, N. (2004). Communication for Development in Research, Extension and Education. In 9th UN Roundtable on Communication for Developmen (pp. 1-28). 
Ropiah, A. (2010). Efektivitas komunikasi dalam pembentukan opini publik tentang PT. Indocement Tunggal Prakarsa Tbk (Kasus Proyek Tanaman Jarak Pagar (Jatropha curcas linn) di Desa Lulut, Kecamatan Klapanunggal, Kabupaten Bogor, Provinsi Jawa Barat). Institut Pertanian Bogor. Retrieved

from https://repository.ipb.ac.id/jspui/bitstream/123456789/60025/1/I10aro1.pdf

Singh, S. (2014). Women, environment and sustainable development: A case study of khul gad micro watershed of kumoun himalaya. Space and Culture, India, 1(3), 53-64. https://doi.org/10.20896/saci.v1i3.45

Subekti, A. I. (2017). Peran Perempuan Dalam Pariwisata Di Desa Wisata Wukirsari Kecamatan Imogiri Kabupaten Bantul. Universitas Negeri Yogyakarta.

Sundberg, J. (2017). Feminist political ecology Sites of inspiration and formation. The International Encyclopedia of Geography, 12. https://doi.org/10.1002/9781118786352.wbieg0804

Terefe, B. (2020). Gender Assessment of Plantwise Programme.

Terrell, S. R., \& Ph, D. (2012). Mixed-Methods Research Methodologies Abstract and Key Words (Vol. 17).

UNWTO. (2019). International Tourism Highlights Presents A Concise Overview of International Tourism in The World Based on The Results for The Year 2018. Retrieved from https://www.eunwto.org/doi/book/10.18111/9789284421152 